ISSN 0258-7122

Bangladesh J. Agril. Res. 40(1): 77-93, March 2015

\title{
SEED YIELD, NUTRIENT BALANCE AND ECONOMICS OF MUNGBEAN CULTIVATION AS INFLUENCED BY DIFFERENT NUTRIENTS MANAGEMENT UNDER AEZ-28
}

\author{
M. A. H. S. JAHAN ${ }^{1}$, M. A. R. SARKAR ${ }^{2}$, N. C. D. BARMA ${ }^{3}$ \\ M. N. A. MONDAL ${ }^{4}$ AND M. N. S. FERdousi ${ }^{5}$
}

\begin{abstract}
A field experiment was conducted at Regional Wheat Research Centre of the Bangladesh Agricultural Research Institute, Joydebpur, Gazipur, Bangladesh for 2 consecutive years during 2007 and 2008 to find out the optimum nutrient management practice for seed yield, nutrient balance and economics of mungbean. Twelve nutrient management treatments were tested in RCBD with 3 replications. Treatments were without CRI $\mathrm{T}_{1}=\mathrm{HYG}(0-24-40-48-24-3-1.2)$, $\mathrm{T}_{2}=$ MYG $(0-20-36-40-20-2-1), \mathrm{T}_{3}=$ IPNS $(5000-9-37-36-21-3-1.2), \mathrm{T}_{4}=\mathrm{STB}(0-$ 20-36-40-22-2-1), $\mathrm{T}_{5}=\mathrm{FP}(0-6-5-4-0-0-0), \mathrm{T}_{6}=\mathrm{CON}(0-0-0-0-0-0-0)$ and with CRI $\quad \mathrm{T}_{7}=\mathrm{HYG}+\mathrm{CRI}, \quad \mathrm{T}_{8}=\mathrm{MYG}+\mathrm{CRI}, \quad \mathrm{T}_{9}=\mathrm{IPNS}+\mathrm{CRI}, \quad \mathrm{T}_{10}=\mathrm{STB}+\mathrm{CRI}$, $\mathrm{T}_{11}=\mathrm{FP}+\mathrm{CRI}, \mathrm{T}_{12}=\mathrm{CON}+\mathrm{CRI} \mathrm{kg} \mathrm{ha}^{-1} \mathrm{CDNPKSZnB}$ for mungbean. The maximum seed yield of mungbean was obtained from STB+CRI $\left(1.57 \mathrm{t} \mathrm{ha}^{-1}\right)$ followed by IPNS+CRI $\left(1.54 \mathrm{t} \mathrm{ha}^{-1}\right)$, STB $\left(1.54 \mathrm{t} \mathrm{ha}^{-1}\right)$, IPNS $\left(1.52 \mathrm{t} \mathrm{ha}^{-1}\right)$, HYG+CRI (1.44 t ha $\left.{ }^{-1}\right)$ and HYG $\left(1.41 \mathrm{t} \mathrm{ha}^{-1}\right)$ in 2007. Similar trend was found in 2008. Numerically higher yield and yield contributing parameters were noticed in CRI plots than without CRI. $\mathrm{N}$ and $\mathrm{K}$ balance were found negative in all the treatments. $\mathrm{P}, \mathrm{S}, \mathrm{Zn}$ and B balance were found positive in case of HYG, MYG, IPNS and STB along with or without CRI nutrient managements. While in case of FP and CON, the balance was shown almost negative. The maximum gross return and margin was obtained from STB+CRI followed by STB. Slightly higher BCR (3.00) was recorded from STB followed by STB+CRI (2.91).
\end{abstract}

Keywords: Mungbean, Seed yield, Economics, Nutrient balance and Crop Residue Incorporation.

\section{Introduction}

Bangladesh is a small country of 0.148 million sq.km and it has to feed about 145 million people of this country (BBS, 2012). In order to produce more food within a limited area, two most important techniques are to be adopted, which is to increase the productive efficiency of the individual crop depending on how well

\footnotetext{
${ }^{1}$ Principal Scientific Officer, Regional Wheat Research Center, Bangladesh Agricultural Research Institute (BARI), Joydebpur, Gazipur, ${ }^{2}$ Professor, Department of Agronomy, Bangladesh Agricultural University (BAU), Mymensingh, ${ }^{3}$ Chief Scientific Officer, Regional Wheat Research Center, BARI, Joydebpur, Gazipur, ${ }^{4}$ Chief Scientific Officer, Regional Agricultural Research Station, BARI, Ishurdi, Pabna, ${ }^{5}$ SASP, PBI, BP, Dhaka, Bangladesh.
} 
it utilizes the basic resources especially, water and nutrients. Bangladesh grows different types of pulse crops. Among the mmungbean is one of the important one for its short duration character (Ahmed et al., 1978). In our country mungbean ranks third in respect of acreage and production while it ranks first in respect of market price. Mungbean grain contains 51\% carbohydrate, $26 \%$ protein, $10 \%$ moisture, $4 \%$ mineral and 3\% vitamins (Kaul, 1982). Moreover, its residues have capacity to improve the soil fertility thus increase the productivity of land. The average yield of mungbean is $0.69 \mathrm{t} \mathrm{ha}^{-1}$ which is very low compared to other mungbean growing countries. There are many reasons of low yield of mungbean of which optimum fertilizer from both organic and inorganic sources along with crop residue management are important which affect the yield contributing characters and seed yield of mungbean. Therefore, the present study was undertaken with the objectives to find out the optimum nutrient management practice for seed yield, apparent nutrient balance in soil and economics of mungbean cultivation under AEZ-28.

\section{Materials and method}

The experiment was carried out at the Regional Wheat Research Centre of Bangladesh Agricultural Research Institute Joydebpur, Gazipur. The experimental field of Gazipur belongs to the agro-ecological zone of Modhupur Tract (AEZ-28). Mungbean was grown in the same location. The initial soil of the experimental field was analyzed for chemical properties before setting up the experiment. The initial soil status was $\mathrm{pH} 6.48, \mathrm{OM}(\%)$ 1.07, Total N (\%) 0.055 , available $\mathrm{P}\left(\mu \mathrm{g} \mathrm{g}^{-1}\right) 3.76$, exchangeable $\mathrm{K}\left(\right.$ meq $\left.100 \mathrm{~g}^{-1}\right) 0.15$, available $\mathrm{S}\left(\mu \mathrm{g} \mathrm{g} \mathrm{g}^{-1}\right)$ 9.91, available $\mathrm{Zn}\left(\mu \mathrm{g} \mathrm{g}^{-1}\right) 0.24$ and available B $\left(\mu \mathrm{g} \mathrm{g}^{-1}\right)$ 0.16. Morphological characters are Grey Terrace soils, medium high land, not well drained, above flood level and grey soil clour. From the initial status of the soil, it was observed that physical characters are silty loam to loam having more or less near neutral soil $\mathrm{pH}$ with very low to low soil fertility level. Mungbean (BARI Mug 6), variety was tested in Kharif-I season during 2007 and 2008. Twelve nutrient management treatments were tested in RCBD with 3 replications. Treatments were $\mathrm{T}_{1}=\mathrm{HYG}(0-24-40-48-24-3-1.2), \mathrm{T}_{2}=\mathrm{MYG}(0-20-36-40-20-2-1), \mathrm{T}_{3}=\mathrm{IPNS}$ (5000-9-37-36-21-3-1.2), $\mathrm{T}_{4}=\mathrm{STB}(0-20-36-40-22-2-1), \mathrm{T}_{5}=\mathrm{FP}(0-6-5-4-0-0-0)$, $\mathrm{T}_{6}=\mathrm{CON} \quad(0-0-0-0-0-0-0), \quad \mathrm{T}_{7}=\mathrm{HYG}+\mathrm{CRI}, \quad \mathrm{T}_{8}=\mathrm{MYG}+\mathrm{CRI}, \quad \mathrm{T}_{9}=\mathrm{IPNS}+\mathrm{CRI}$, $\mathrm{T}_{10}=\mathrm{STB}+\mathrm{CRI}, \quad \mathrm{T}_{11}=\mathrm{FP}+\mathrm{CRI}, \quad \mathrm{T}_{12}=\mathrm{CON}+\mathrm{CRI} \quad \mathrm{kg} \mathrm{ha}^{-1}$ CDNPKSZnB for mungbean. The previous crop was potato and total foliage (haulm) as residue of potato was incorporated before mungbean sowing. The rates for $\mathrm{N}, \mathrm{P}, \mathrm{K}, \mathrm{S}, \mathrm{Zn}$ and $\mathrm{B}$ application were calculated based on the soil test value following the soil test interpretation (BARC, 2005). Accordingly, the full or $100 \%$ rate of N, P, K, $\mathrm{S}, \mathrm{Zn}$ and $\mathrm{B}$ for each crop was applied. In case of Integrated Plant Nutrient System (IPNS) treatment the amount of nutrients available in cowdung (CD) was deducted from the total amount of chemical fertilizers and adjusted accordingly. 
The rates for chemical fertilizers were fixed on soil test basis (STB) with a high yield goal (HYG) for specific crop basis as per BARC, 2005. The exact fertilizer nutrient for making the recommendation was computed with the following formula:

$\mathrm{F}_{\mathrm{r}}=\mathrm{U}_{\mathrm{f}}-\frac{\mathrm{C}_{\mathrm{i}}}{\mathrm{C}_{\mathrm{s}}} \times\left(\mathrm{S}_{\mathrm{t}}-\mathrm{L}_{\mathrm{s}}\right)$

Where

$F_{r}=$ Fertilizer nutrient required for a given soil test value

$\mathrm{U}_{\mathrm{f}}=$ Upper limit of the recommended fertilizer nutrient for the respective soil test value interpretation (STVI) class

$C_{i}=$ Units of class intervals used for fertilizer nutrient recommendation

$\mathrm{C}_{\mathrm{s}}=$ Units of class intervals used for STVI class

$\mathrm{S}_{\mathrm{t}}=$ Soil test value

$\mathrm{L}_{\mathrm{s}}=$ Lower limit of the soil test value within STVI class.

For HYG, MYG and IPNS management recommended cowdung was adjusted into chemical nutrient and added according to the thumb rule i.e. 1 ton decomposed cowdung contains $3 \mathrm{~kg} \mathrm{~N}, 0.6 \mathrm{~kg} \mathrm{P}, 2.4 \mathrm{~kg} \mathrm{~K}$ and $0.6 \mathrm{~kg} \mathrm{~S}$ (BARC, 2005). The sources of $\mathrm{N}, \mathrm{P}, \mathrm{K}, \mathrm{S}, \mathrm{Zn}$ and $\mathrm{B}$ were urea, triple super phosphate (TSP), muriate of potash (MoP), gypsum, zincsulphate and boric acid, respectively. The farmers' practice (FP) for fertilizer rates was determined on the basis of data collected through interviewing thirty (30) farmers from adjacent locality. It appeared that the farmers generally did not use $\mathrm{S}, \mathrm{Zn}$ and B fertilizers. Residue of previous potato crop was in-situ incorporated to the soil for crop residue incorporation plots only. Total fresh residue was chopped just after harvest and ploughed down to the soil by spade for decomposition in respective CRI plots with available moisture consequently that was decomposed. Moreover a light irrigation was applied for germination of mungbean seed which enhanced the decomposition of residue. Turn Around Time (TAT) was about 10-15 days potato harvest and mungbean sowing. Seeds were sown on 5-7 March each year in $30 \mathrm{~cm}$ of continuous solid lines @ $40 \mathrm{~kg} \mathrm{ha}^{-1}$ and seeds were covered with soil. The whole amount of urea TSP, MoP, gypsum, zincsulphate and boric acid were applied at the time of final land preparation as per treatment. The mungbean field was then irrigated at 15 and 30 days after germination. Weeding and plant protection measures were followed as and when necessary. Mungbean was harvested on 25-31 May each year. The crops were harvested at full maturity. An area of $10 \mathrm{~m}^{2}$ in each plot was harvested to record seed and biomass yields. A sub-sample of $200 \mathrm{~g}$ dry biomass for each of crop was collected for chemical (nutrient uptake) analysis. The data on the yield contributing characters were 
recorded from 10 randomly selected plants for mungbean. For dry biomass yield, total fresh biomass yield was measured from the harvested area. Then a subsample from each plot was collected and weighed to record fresh weight. The sub-samples were dried in an oven for 72 hours at $70^{\circ} \mathrm{C}$. Oven dry of each sample was recorded and expressed as dry biomass yield $\left(\mathrm{t} \mathrm{ha}^{-1}\right)$. Apparent nutrient balance (added-uptake) was calculated using the following formula.

$$
X_{a}=\left(X_{f}+X_{r}+X_{i}+X_{b}+X_{c r i}\right)-X_{r e m}
$$

Where

$$
\begin{array}{ll}
\mathrm{Xa}= & \text { Apparent gain }(+) \text { or loss }(-) \text { of nutrient }\left(\mathrm{kg} \mathrm{ha}^{-1}\right) \\
\mathrm{Xf}= & \text { Nutrient added through inorganic sources }\left(\mathrm{kg} \mathrm{ha}^{-1}\right) \\
\mathrm{Xr}= & \text { Nutrient added through rainfall }\left(\mathrm{kg} \mathrm{ha}^{-1}\right) .(\text { Not considered }) \\
\mathrm{Xi}= & \text { Nutrient added through irrigation water }\left(\mathrm{kg} \mathrm{ha}^{-1}\right) .(\text { Not considered }) \\
\mathrm{Xb}= & \text { Nutrient added through BNF }\left(\mathrm{kg} \mathrm{ha}^{-1}\right) .(\text { Not considered }) \\
\mathrm{Xcri}= & \text { Nutrient added through crop residue incorporation }\left(\mathrm{kg} \mathrm{ha}^{-1}\right) . \\
\mathrm{Xrem}= & \text { Nutrient removed by crops and loss through different systems }\left(\mathrm{kg} \mathrm{ha}^{-1}\right) .
\end{array}
$$

\begin{tabular}{|c|c|c|c|c|c|c|c|c|c|c|c|c|}
\hline \multirow{3}{*}{$\begin{array}{c}\text { Nutrient } \\
\text { management }\end{array}$} & \multirow{2}{*}{\multicolumn{2}{|c|}{$\frac{\mathrm{kg} \mathrm{ha}^{-1}}{\mathrm{~N}}$}} & \multirow{2}{*}{\multicolumn{2}{|c|}{$\frac{\mathrm{kg} \mathrm{ha}^{-1}}{\mathrm{P}}$}} & \multirow{2}{*}{\multicolumn{2}{|c|}{$\frac{\mathrm{kg} \mathrm{ha}^{-1}}{\mathrm{~K}}$}} & \multirow{2}{*}{\multicolumn{2}{|c|}{$\frac{\mathrm{kg} \mathrm{ha}^{-1}}{\mathrm{~S}}$}} & \multirow{2}{*}{\multicolumn{2}{|c|}{$\frac{\mathrm{kg} \mathrm{ha}^{-1}}{\mathrm{Zn}}$}} & \multirow{2}{*}{\multicolumn{2}{|c|}{$\frac{\mathrm{kg} \mathrm{ha}^{-1}}{\mathrm{~B}}$}} \\
\hline & & & & & & & & & & & & \\
\hline & 2007 & 2008 & 2007 & 2008 & 2007 & 2008 & 2007 & 2008 & 2007 & 2008 & 2007 & 2008 \\
\hline $\mathrm{HYG}+\mathrm{CRI}$ & 17 & 18 & 11 & 12 & 41 & 44 & 9 & 9 & 0.14 & 0.15 & 0.10 & 0.11 \\
\hline MYG+CRI & 11 & 12 & 8 & 9 & 32 & 35 & 8 & 8 & 0.11 & 0.08 & 0.08 & 0.07 \\
\hline IPNS+CRI & 13 & 15 & 10 & 11 & 40 & 44 & 9 & 9 & 0.13 & 0.14 & 0.09 & 0.09 \\
\hline $\mathrm{STB}+\mathrm{CRI}$ & 13 & 14 & 10 & 11 & 37 & 40 & 9 & 10 & 0.11 & 0.12 & 0.09 & 0.08 \\
\hline $\mathrm{FP}+\mathrm{CRI}$ & 9 & 10 & 7 & 8 & 24 & 28 & 6 & 7 & 0.08 & 0.09 & 0.07 & 0.07 \\
\hline $\mathrm{CON}+\mathrm{CRI}$ & 6 & 6 & 4 & 4 & 17 & 17 & 4 & 4 & 0.05 & 0.05 & 0.04 & 0.03 \\
\hline
\end{tabular}

Data were analyzed statistically by the F-test to examine whether the treatment effects were significant. The mean comparisons of the treatments were evaluated by DMRT (Duncan's Multiple Range Test).

Table 1.Total addition of extra nutrients into the soil through crop residues incorporation in mungbean $\left(\mathrm{kg} \mathrm{ha}^{-1} \mathrm{yr}^{-1}\right)$ during $2007 \& 2008$ (Assuming nitrogen mineralization rate $40 \%$ ).

On an average of two years, major plant nutrients like $\mathrm{N}$ (6 to $\left.18 \mathrm{~kg} \mathrm{ha}^{-1} \mathrm{yr}^{-1}\right), \mathrm{P}$ (4 to $12 \mathrm{~kg} \mathrm{ha}^{-1} \mathrm{yr}^{-1}$ ), $\mathrm{K}$ (17 to $44 \mathrm{~kg} \mathrm{ha}^{-1} \mathrm{yr}^{-1}$ ), S (4 to $10 \mathrm{~kg} \mathrm{ha}^{-1} \mathrm{yr}^{-1}$ ) and minor nutrients like $\mathrm{Zn}\left(0.05\right.$ to $\left.0.15 \mathrm{~kg} \mathrm{ha}^{-1} \mathrm{yr}^{-1}\right)$ and $\mathrm{B}\left(0.03\right.$ to $\left.0.11 \mathrm{~kg} \mathrm{ha}^{-1} \mathrm{yr}^{-1}\right)$ were added into the soil through crop residues incorporation. The amount was varied depend on irrespective treatment as well as the crop growth. That was an approach for conservation agriculture which might have played a vital role for 
sustaining soil health like fertility and productivity. This approach might be helpful for a long run.

\section{Results and discussion}

\section{Plants population}

The number of plants $\mathrm{m}^{-2}$ did not vary significantly by different nutrient management treatments in both the years (Table 2).

\section{Plant height}

The nutrient management treatments without or with crop residues incorporation significantly influenced the plant height in both the years. The significantly taller plant was recorded under HYG with crop residues incorporation $(37.2 \mathrm{~cm})$ followed by remaining nutrient management treatments except, FP without CRI, control without and with CRI $(28.4 \mathrm{~cm})$. The treatment HYG+CRI produced the tallest plant $(42.1 \mathrm{~cm})$ which was statistically identical to HYG $(41.6 \mathrm{~cm})$, IPNS+CRI $(41.1 \mathrm{~cm})$ and STB+CRI $(40.6 \mathrm{~cm})$. The plant height under different nutrient management ranged from $30.3 \mathrm{~cm}$ to $36.1 \mathrm{~cm}$ whereas lowest $(28.1 \mathrm{~cm})$ in control in Table 2. However, the trend of plant height was observed more or less similar over the years that might be due to similar nutrient management but tendency is taller plant in CRI incorporation treatment might be due to crop residue effect (Naser et al., 2001).

\section{Pods plant ${ }^{-1}$}

Number of pods plant ${ }^{-1}$ differed significantly due to application of nutrients without or with crop residues incorporation in 2007 (Table 2). The significant more number of pods plant $^{-1}$ (12.13) was obtained from STB+CRI followed by STB (12.10), IPNS+CRI (12.01), IPNS (11.98), HYG+CRI (10.83) and HYG (10.80). The lowest number was found in control (4.80) treatment. In 2008, the trend of number of pods plant ${ }^{-1}$ due to nutrient management treatments was similar previous year.

The highest number of pods palnt ${ }^{-1}$ was obtained from the treatment STB without or with crop residues incorporation that might be due to proper nutrient management followed by IPNS and HYG without or with CRI. Similar findings were reported by Singh and Pareek (2003) where the highest number of pods plant $^{-1}$ was recorded with nutrient applied @ $\mathrm{P}_{2} \mathrm{O}_{545} \mathrm{~kg} \mathrm{ha}^{-1}$ in mungbean. In another field experiment, Quayyum et al. (2002) also reported that STB nutrient $\mathrm{N}_{20} \mathrm{P}_{20} \mathrm{~K}_{20}$ gave the highest number of pods plant ${ }^{-1}$ in wheat-mungbean- T. Aman rice cropping pattern. 


\section{Pod length}

The nutrient management packages had significant effect on the length of pod in 2007. However, the nutrient management treatments HYG, MYG, IPNS, and STB without and with CRI showed statistically identical length of pod with exception of MYG without CRI. While in 2008, the maximum length of pod $(9.65 \mathrm{~cm})$ was obtained under STB+CRI which were statistically identical to all treatments except control. The minimum length of pod was recorded under control without CRI in both the years (Table 2).

However, the length of pod was more or less similar over the years might be due to the effect of similar nutrient management.

\section{Seeds $\operatorname{pod}^{-1}$}

Different nutrient management treatments showed significant effect on seeds $\operatorname{pod}^{-1}$ (Table 2). Among the treatments, STB+CRI gave the maximum seeds pod ${ }^{-1}$ (9.81) followed by HYG and IPNS without or with CRI, and were statistically identical. Number of seeds pod ${ }^{-1}$ was the lowest (5.37) in control in 2007. During 2008, most of the nutrient management treatments except, MYG, FP and control without or with CRI were statistically identical and varied from 9.53 to 10.43 . The maximum number of seeds $\operatorname{pod}^{-1}(10.43)$ was obtained under STB+CRI followed by STB (10.42). FP showed lower seeds pod $^{-1}$ in both the years.

The higher number of seeds pod $^{-1}$ in case of CRI treatment might be due to the effect of the crop residues incorporation. Similar trend was observed over the years because the nutrient management treatments were same in both the years. Similar findings were reported by Siag and Yadav (2003) where the maximum number of seeds pod ${ }^{-1}$ was obtained when nutrient was applied @ $\mathrm{S}_{40} \mathrm{~kg} \mathrm{ha}^{-1}$ in mungbean.

\section{Seed weight}

The nutrient management treatments HYG, IPNS and STB without and with CRI produced significantly higher 1000-seed weight that ranged from 45.77 to 47.57 g. Among the treatments, STB+CRI gave the maximum 1000-seed weight (47.57 g). The lowest 1000 -seed weight $(35.17 \mathrm{~g})$ was recorded under the control treatment. Similar trend was found in 2008 but the values were higher than the previous year that might be due to crop residue incorporation (Table 2).

This observation might be due to residual effect of the crop residues although it was statistically identical in other crop in rice Naser et al., 2001. In another field study, Singh and Pareek (2003) reported the maximum 1000-seed weight by using nutrient @ $\mathrm{P}_{2} \mathrm{O}_{545} \mathrm{~kg} \mathrm{ha}^{-1}$ on mungbean. 


\section{Seed yield}

Most of the nutrient management treatments except MYG, FP and control without or with crop residue incorporation were statistically identical for seed yield in 2007. All those treatments yielded 1.41 to $1.57 \mathrm{t} \mathrm{ha}^{-1}$ and were superior to MYG, FP and control with or without crop residue incorporation. The treatment STB+CRI produced the highest seed yield $\left(1.57 \mathrm{t} \mathrm{ha}^{-1}\right)$. On the other hand, MYG without or with CRI produced 1.24 and $1.26 \mathrm{t} \mathrm{ha}^{-1}$, respectively. FP produced lower yield in the range of 0.63 to $0.64 \mathrm{t} \mathrm{ha}^{-1}$. The lowest yield was $0.33 \mathrm{t} \mathrm{ha}^{-1}$ in control plot. In 2008, the trend of seed yield due to nutrient management treatments was similar to the findings of previous year.

Moreover, it was observed that the nutrient management treatments like, HYG, IPNS and STB without or with crop residues incorporation gave higher seed yield. These results might be due to the cumulative effect of higher number of pods plant ${ }^{-1}$, seeds pod $^{-1}$ and 1000 -seed weight. Among the treatments, STB produced the highest yield while lowest seed yield in control. However, the seed yield was numerically higher, though not statistically significant in all the treatments along with crop residues incorporation than without CRI might be due to effect of crop residue incorporation as well as more soil microbial activities for having conservation agriculture. Similar results were reported by Akhterruzzaman et al. (2009) where they observed the highest seed yield of mungbean with STB nutrient $\left(\mathrm{N}_{22} \mathrm{P}_{9} \mathrm{~K}_{11} \mathrm{~S}_{2} \mathrm{~kg} \mathrm{ha}^{-1}\right)$ in wheat-mungbean- $\mathrm{T}$. Aman rice cropping pattern in high Ganges river floodplain soil. Timsina et al. (2006 a) reported the maximum seed yield from STB nutrient @ $\mathrm{N}_{20} \mathrm{P}_{20} \mathrm{~K}_{20}$ in wheat-mungbean-T. Aman rice cropping pattern in northern part of Bangladesh. In addition, Chowdhury et al. (2002) revealed that STB nutrient N ${ }_{15} \mathrm{P}_{15} \mathrm{~K}_{0} \mathrm{~S}_{10} \mathrm{~kg} \mathrm{ha}^{-1}$ gave the highest mungbean seed yield in wheatmungbean-T. Aman rice cropping pattern. Moreover, these results were also in agreement with other authors (Saha et al., 2000; Quayyum et al., 2001 and 2002; Singh et al., 2003).

\section{Dry biomass yield}

The maximum dry biomass yield $\left(2.36 \mathrm{t} \mathrm{ha}^{-1}\right)$ was obtained from HYG+CRI, which was statistically identical to HYG $\left(2.32 \mathrm{t} \mathrm{ha}^{-1}\right)$, IPNS+CRI $\left(2.29 \mathrm{t} \mathrm{ha}^{-1}\right)$, IPNS $\left(2.27 \mathrm{t} \mathrm{ha}^{-1}\right)$, STB+CRI $\left(2.14 \mathrm{t} \mathrm{ha}^{-1}\right)$ and STB $\left(2.10 \mathrm{tha}^{-1}\right)$. The trend was similar to the previous year with some exception in 2008. HYG+CRI produced the highest biomass yield $\left(2.51 \mathrm{t} \mathrm{ha}^{-1}\right)$, which was statistically identical to a number of treatments. The lowest biomass yield of 097 and $1.01 \mathrm{t} \mathrm{ha}^{-1}$ was recorded in control treatment in 2007 and 2008 (Table 2). 


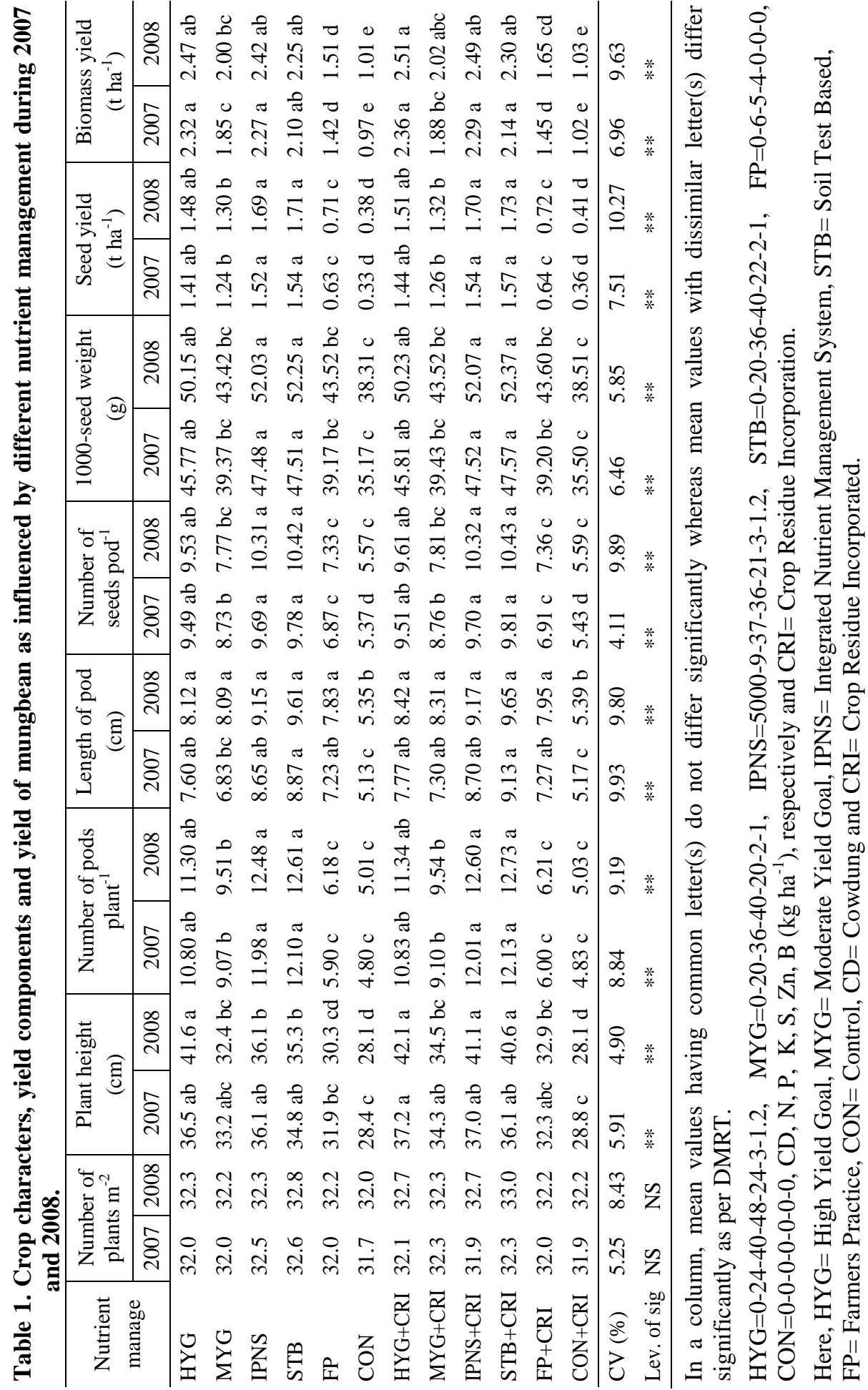


From the results of two years, it was found that HYG, IPNS and STB nutrient management treatments without or with CRI gave higher dry biomass yield. These results might be due to the effect of proper nutrient management, while MYG and FP gave and low biomass yield might be due to the effect of respective nutrient management. The lowest biomass yield was noticed in control as influenced no nutrient added into the soil i.e. native nutrient effect. However, over all the trend was more or less similar over the years might be due to applying the same nutrient management treatments. Chowdhury et al. (2002) reported that STB nutrient $\mathrm{N}_{15} \mathrm{P}_{15} \mathrm{~K}_{0} \mathrm{~S}_{10} \mathrm{~kg} \mathrm{ha}^{-1}$ produced the highest dry biomass yield in wheat-mungbean-T. Aman rice cropping pattern.

\section{Apparent nutrient uptake and balance}

Total nutrient uptake (seed+ biomass) of N P K S Zn and B was significantly influenced by different nutrient management treatments in 2007 and 2008 for mungbean (statistically analyzed but not shown here) and balance (two years mean) (not statistically analyzed) was calculated normally and discussed below (Fig. 1-6).

\section{Nitrogen}

From the mean data it was observed that the added of nutrient ranged from 0 to $41 \mathrm{~kg} \mathrm{ha}^{-1} \mathrm{yr}^{-1}$ (40\% of applied chemical/cowdung/crop residues nutrient $\mathrm{N}$ was considered effective) while uptake ranged from 26 to $93 \mathrm{~kg} \mathrm{ha}^{-1} \mathrm{yr}^{-1}$ among different treatments (Fig.1). Maximum uptake was found in STB (93 kg ha $\mathrm{yr}^{-1}$ ) followed by STB+CRI (91 kg ha $\left.\mathrm{yr}^{-1}\right)$. Minimum uptake was estimated in CON (26 kg ha $\left.\mathrm{yr}^{-1}\right)$. The apparent nutrient balance was found negative in all treatments ranging from -26 to $-73 \mathrm{~kg} \mathrm{ha}^{-1} \mathrm{yr}^{-1}$. The highest negative balance was found in STB (-73 $\left.\mathrm{kg} \mathrm{ha}^{-1} \mathrm{yr}^{-1}\right)$ followed by HYG and IPNS $\left(-65 \mathrm{~kg} \mathrm{ha}^{-1} \mathrm{yr}^{-1}\right)$. The lowest negative balance was observed in CON+CRI $\left(-21 \mathrm{~kg} \mathrm{ha}^{-1} \mathrm{yr}^{-1}\right)$.

Fig. 1, shows that the nitrogen balance was negative as the uptake was higher compared to added nitrogen (40\% of applied chemical/cowdung/crop residues nutrient $\mathrm{N}$ was considered effective). The $\mathrm{N}$ balance thus was negative in all treatments appeared to have been removed in excess of the quantity added in soil. However, the $\mathrm{N}$ balance was less negative in those treatments where crop residues were incorporated than without incorporation which might be due to addition of extra $\mathrm{N}$ came from crop residues (6 to $18 \mathrm{~kg} \mathrm{ha}^{-1} \mathrm{yr}^{-1}$ ) as shown (Table 2). Present findings are also in agreement with some other researchers (Timsina et al., 2001 and 2006 (b)).

\section{Phosphorus}

The added phosphorus was in the range from 0 to $52 \mathrm{~kg} \mathrm{ha}^{-1} \mathrm{yr}^{-1}$ in respective of different treatments. The uptake was ranged from 5 to $19 \mathrm{~kg} \mathrm{ha}^{-1} \mathrm{yr}^{-1}$. The 
treatments STB +CRI showed the highest uptake $\left(19 \mathrm{~kg} \mathrm{ha}^{-1} \mathrm{yr}^{-1}\right)$ followed by IPNS+CRI $\left(18 \mathrm{~kg} \mathrm{ha}^{-1} \mathrm{yr}^{-1}\right)$. The lowest uptake was found in CON and CON+CRI $\left(5 \mathrm{~kg} \mathrm{ha}^{-1} \mathrm{yr}^{-1}\right)$. The negative balance was found in CON+CRI and CON -1 and -5 $\mathrm{kg} \mathrm{ha}^{-1} \mathrm{yr}^{-1}$, respectively and FP $\left(-5 \mathrm{~kg} \mathrm{ha}^{-1} \mathrm{yr}^{-1}\right)$ nutrient management treatments from mean data shown in Fig. 2. On the other hand, remaining treatments showed positive balance in the range of 3-35 $\mathrm{kg} \mathrm{ha}^{-1} \mathrm{yr}^{-1}$. Maximum positive balance was found in HYG+CRI (35 $\left.\mathrm{kg} \mathrm{ha}^{-1} \mathrm{yr}^{-1}\right)$ followed by IPNS+CRI $\left(33 \mathrm{~kg} \mathrm{ha}^{-1} \mathrm{yr}^{-1}\right)$. Minimum positive balance was noticed in FP+CRI ( $\left.3 \mathrm{~kg} \mathrm{ha}^{-1} \mathrm{yr}^{-1}\right)$.

From the figure 2, it was observed that the except FP and CON without or with crop residue incorporation treatments showed positive balance due to addition of higher amount of phosphorus nutrient with lower nutrient uptake that might be due to total dry matter content as well as the variation of concentration of the nutrient of the crops. Similar results were also found by Saleque et al. (2006).

\section{Potassium}

The quantity of added nutrient (K) was in the range of 0 to $90 \mathrm{~kg} \mathrm{ha}^{-1} \mathrm{yr}^{-1}$ and uptake by the crop varied from 21 to $65 \mathrm{~kg} \mathrm{ha}^{-1} \mathrm{yr}^{-1}$. Maximum uptake was found in IPNS+CRI and STB+CRI (65 kg ha $\left.\mathrm{yr}^{-1}\right)$ followed by IPNS and STB (64 kg $\left.\mathrm{ha}^{-1} \mathrm{yr}^{-1}\right)$. Minimum uptake was observed in CON $\left(21 \mathrm{~kg} \mathrm{ha}^{-1} \mathrm{yr}^{-1}\right)$. Among the nutrient managements, all treatments showed negative balance in the range of -4 to $-29 \mathrm{~kg} \mathrm{ha}^{-1} \mathrm{yr}^{-1}$ except HYG+CRI, MYG+CRI, IPNS+CRI and STB+CRI. The positive balance ranged from 14 to $31 \mathrm{~kg} \mathrm{ha}^{-1} \mathrm{yr}^{-1}$. Maximum positive balance was observed in $\mathrm{HYG}+\mathrm{CRI}\left(31 \mathrm{~kg} \mathrm{ha}{ }^{-1} \mathrm{yr}^{-1}\right)$ and minimum was found in both $\mathrm{STB}+\mathrm{CRI}\left(14 \mathrm{~kg} \mathrm{ha}^{-1} \mathrm{yr}^{-1}\right)$ as shown in Fig. 3. This result is also agreement with Panaullah et al. (2006) but differed from Rahman et al., 2002.

\section{Sulphur}

From the mean data it was observed that quantity of added nutrient ranged from 0 to $33 \mathrm{~kg} \mathrm{ha}^{-1} \mathrm{yr}^{-1}$ and the uptake ranged from 4 to $15 \mathrm{~kg} \mathrm{ha}^{-1} \mathrm{yr}^{-1}$ with irrespective treatments. Among the treatments, maximum uptake was observed in STB+CRI $\left(15 \mathrm{~kg} \mathrm{ha}^{-1} \mathrm{yr}^{-1}\right)$ followed by IPNS+CRI $\left(13 \mathrm{~kg} \mathrm{ha}^{-1} \mathrm{yr}^{-1}\right)$. Minimum uptake was found in $\mathrm{CON}$ and $\mathrm{CON}+\mathrm{CRI}\left(4 \mathrm{~kg} \mathrm{ha}^{-1} \mathrm{yr}^{-1}\right)$. The negative balance as observed in FP and CON with and without CRI treatments was -1 to $-8 \mathrm{~kg} \mathrm{ha}^{-1} \mathrm{yr}^{-1}$. Remaining treatments showed positive balance ranged from 8 to $22 \mathrm{~kg} \mathrm{ha}^{-1} \mathrm{yr}^{-}$ ${ }^{1}$ shown in Fig. 4. Among the treatments, the maximum positive balance was observed in HYG+CRI $\left(22 \mathrm{~kg} \mathrm{ha}^{-1} \mathrm{yr}^{-1}\right)$ that was followed by IPNS+CRI $(20 \mathrm{~kg}$ $\left.\mathrm{ha}^{-1} \mathrm{yr}^{-1}\right)$. The minimum positive balance was found in MYG $\left(8 \mathrm{~kg} \mathrm{ha}^{-1} \mathrm{yr}^{-1}\right)$.

From the above results it was observed that only two treatments such as FP and CON with and without CRI showed negative balance (two years mean) due to addition of low or no nutrient in the soil as uptake was high which might be due 
to total dry matter accumulation and variation of nutrient concentration of respective treatments. Rest of the treatments showed positive balance that might be due to addition of high amount of nutrient. The result is in agreement with Khan et al. (2005).

\section{Zinc}

The amount of nutrient added in different nutrient treatment was in the range of 0 to $3 \mathrm{~kg} \mathrm{ha}^{-1}$ and uptake was in the range 0.06 to $0.20 \mathrm{~kg} \mathrm{ha}^{-1} \mathrm{yr}^{-1}$ with different treatments shown in Fig 5. Maximum uptake was observed in IPNS $(0.21 \mathrm{~kg}$ ha $\left.{ }^{1} \mathrm{yr}^{-1}\right)$ that was followed by a number of treatments like STB, STB+CRI and IPNS+CRI $\left(0.20 \mathrm{~kg} \mathrm{ha}^{-1} \mathrm{yr}^{-1}\right)$. Minimum uptake was found in CON and $\mathrm{CON}+\mathrm{CRI}\left(0.06 \mathrm{~kg} \mathrm{ha}^{-1} \mathrm{yr}^{-1}\right)$. The highest negative balance was noticed in FP ($\left.0.10 \mathrm{~kg} \mathrm{ha}^{-1} \mathrm{yr}^{-1}\right)$ and the lowest in CON+CRI $\left(-0.01 \mathrm{~kg} \mathrm{ha}^{-1} \mathrm{yr}^{-1}\right)$. Other treatments showed positive balance ranged from 1.80 to $2.96 \mathrm{~kg} \mathrm{ha}^{-1} \mathrm{yr}^{-1}$. Among the treatments, maximum positive balance was noticed in HYG+CRI $\left(2.96 \mathrm{~kg} \mathrm{ha}^{-1} \mathrm{yr}^{-}\right.$ $\left.{ }^{1}\right)$ which was followed by IPNS+CRI $\left(2.93 \mathrm{~kg} \mathrm{ha}^{-1} \mathrm{yr}^{-1}\right)$. Minimum positive balance was observed in STB $\left(1.80 \mathrm{~kg} \mathrm{ha}^{-1} \mathrm{yr}^{-1}\right)$.

From the mean data of two years, it was noticed that farmers' practice and control treatments showed negative balance of zinc. Because there was poor and no nutrient (native nutrient was available only in the soil) was added into the soil whereas a considerable amount of nutrient was removed by the crop through total dry matter production and nutrient concentration variation in respective treatments consequently the balance became negative. On the other hand, rest of the treatments had positive balance. Similar results were reported by Basak et al. (2008) in Groundnut-T.Aus-T.Aman rice cropping pattern.

\section{Boron}

The range of added boron was $0-1.20 \mathrm{~kg} \mathrm{ha}^{-1} \mathrm{yr}^{-1}$ and uptake ranged from 0.04 to $0.15 \mathrm{~kg} \mathrm{ha}^{-1} \mathrm{yr}^{-1}$. The uptake was the highest in STB $\left(0.15 \mathrm{~kg} \mathrm{ha}^{-1}\right)$. The CON and CON+CRI $\left(0.04 \mathrm{~kg} \mathrm{ha}^{-1} \mathrm{yr}^{-1}\right)$ had the lowest uptake. The minimum negative balance was found in FP+CRI and CON+CRI (-0.01 $\left.\mathrm{kg} \mathrm{ha}^{-1} \mathrm{yr}^{-1}\right)$ and the maximum was in FP $\left(-0.07 \mathrm{~kg} \mathrm{ha}^{-1} \mathrm{yr}^{-1}\right)$ in Fig. 6. Other treatments showed positive balance ranged from 0.86 to $1.17 \mathrm{~kg} \mathrm{ha}^{-1}$. The highest positive balance was found in HYG+CRI (1.17 $\left.\mathrm{kg} \mathrm{ha}^{-1} \mathrm{yr}^{-1}\right)$. The lowest positive balance was observed in STB $\left(0.86 \mathrm{~kg} \mathrm{ha}^{-1} \mathrm{yr}^{-1}\right)$. Similar results were reported by Bhuiyan (2004) in Wheat-T. Aus/ Mungbean- T. Aman rice cropping pattern. 


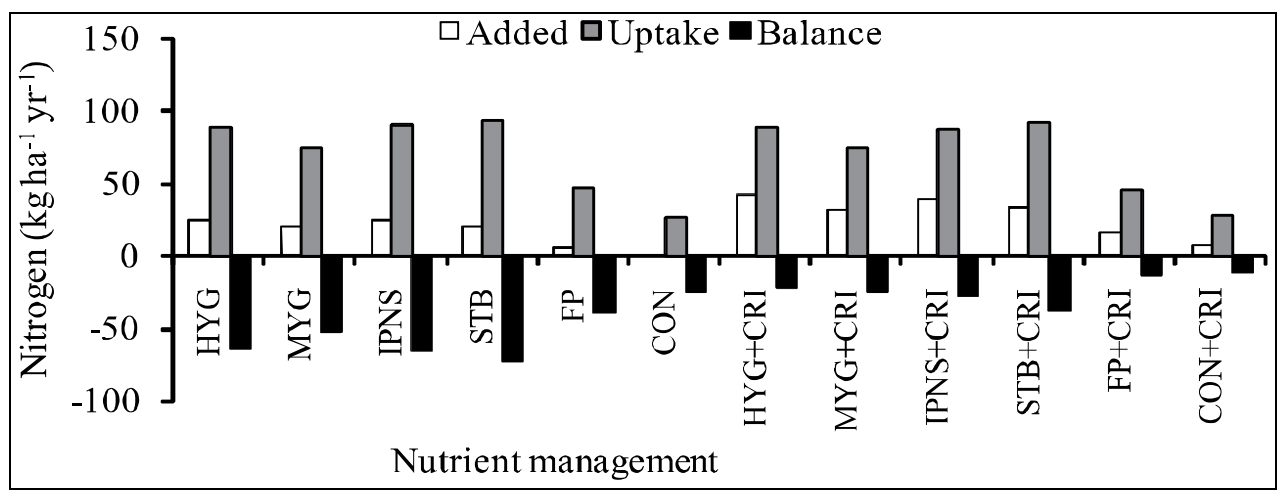

Fig. 1. Apparent $\mathrm{N}$ balance of mungbean as influenced by different nutrient management at ( two years mean)

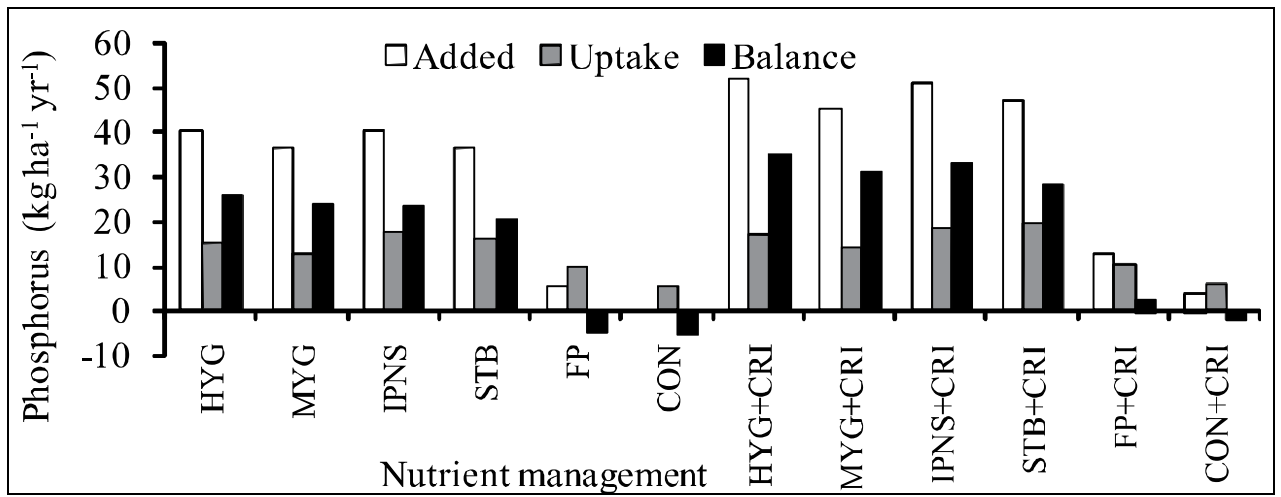

Fig. 2. Apparent $P$ balance of mungbean as influenced by different nutrient management (two years mean)

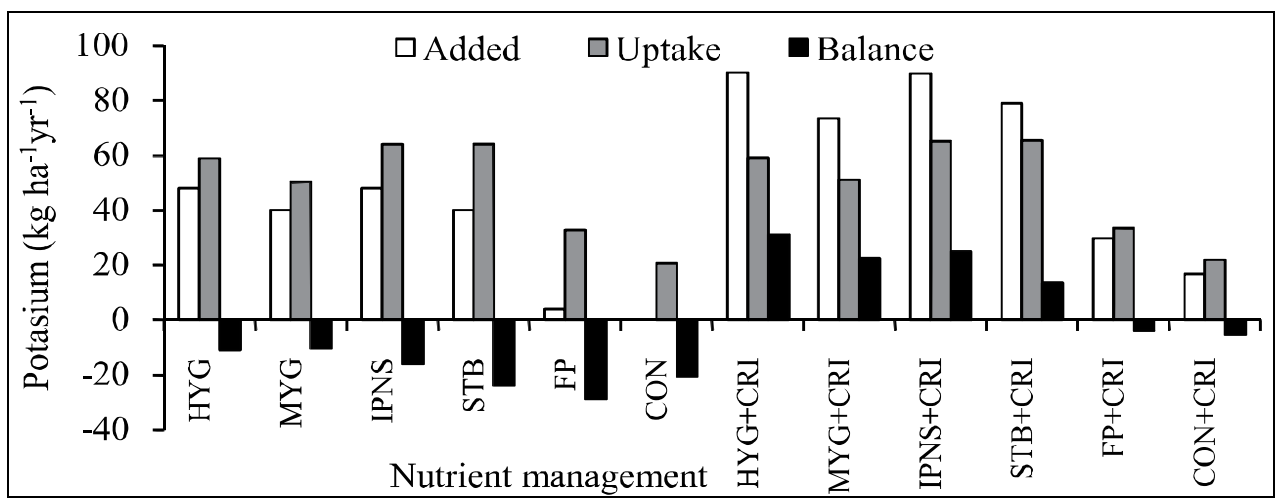

Fig. 3. Apparent $K$ balance of mungbean as influenced by different nutrient management two years mean) 


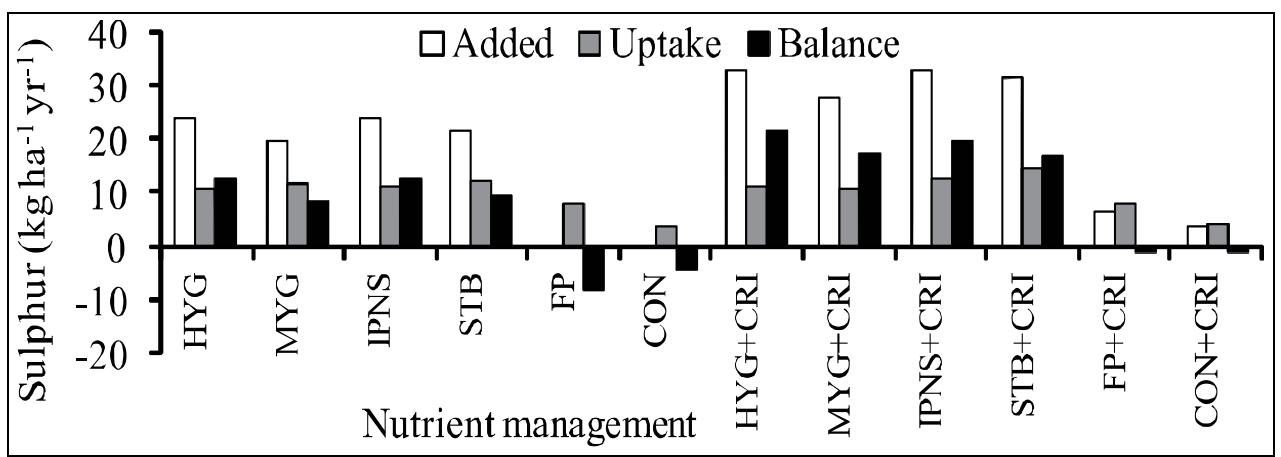

Fig. 4. Apparent $S$ balance of mungbean as influenced by different nutrient management (two years mean)

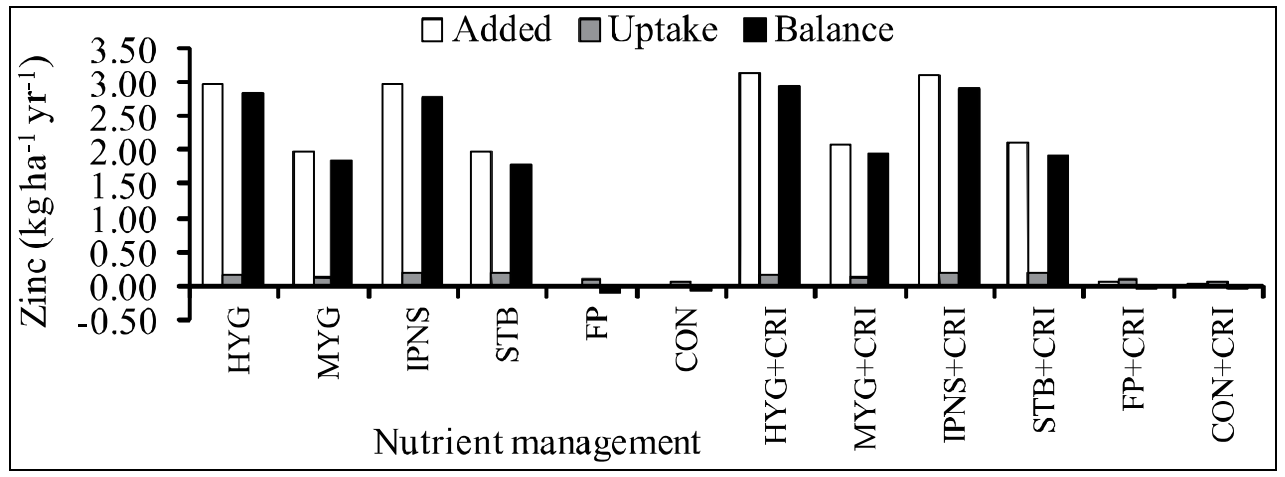

Fig. 5. Apparent $\mathrm{Zn}$ balance of mungbean as influenced by different nutrient mamagement (two years mean).

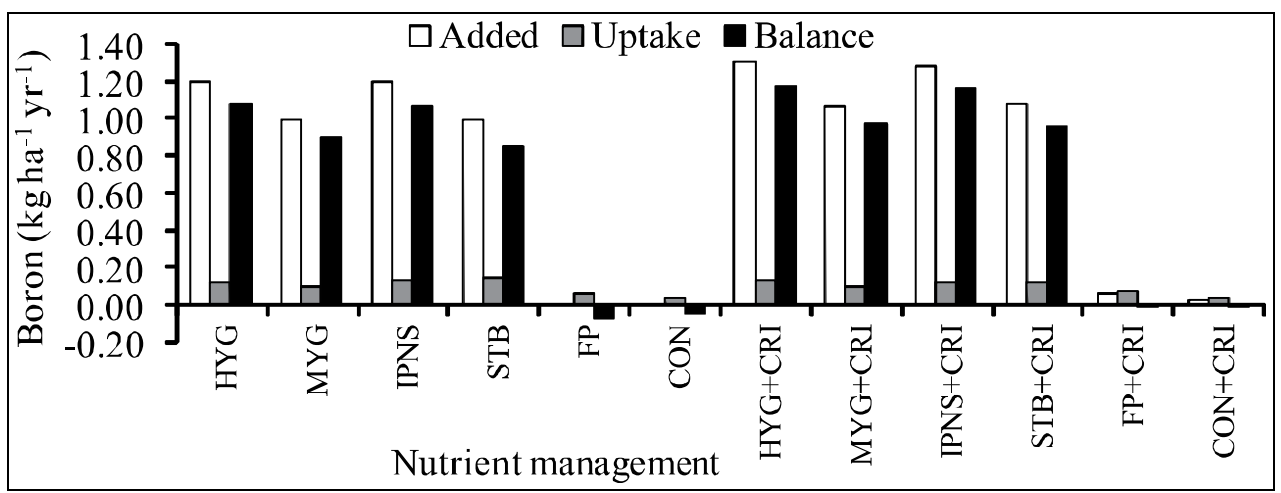

Fig.6. Apparent $B$ balance of mungbean as influenced by different nutrient management (two years mean). 


\section{Economics of mungbean cultivations influenced by different nutrient management}

Average of two years result showed that STB+CRI nutrient management gave the highest gross return (Tk. $41859 \mathrm{ha}^{-1}$ ) followed by STB (Tk. $41224 \mathrm{ha}^{-1}$ ), IPNS+CRI (Tk. $40981 \mathrm{ha}^{-1}$ ), and IPNS (Tk. $40844 \mathrm{ha}^{-1}$ ) nutrient management treatments due to higher yield. Table 3 revealed that STB+CRI nutrient management produced the highest net return (Tk. $\left.27470 \mathrm{ha}^{-1}\right)$ followed by STB (Tk. $27463 \mathrm{ha}^{-1}$ ), IPNS (Tk. $25394 \mathrm{ha}^{-1}$ ), and IPNS+CRI (Tk. $24908 \mathrm{ha}^{-1}$ ) due to lower total costs. In STB nutrient management, the cost of crop residue was not considered in the calculation that resulted in low total cost. Due to higher yield obtained STB nutrient management was much profitable (BCR, 3.00) compared to other nutrient managements like STB+CRI (2.91), IPNS (2.64), and IPNS+CRI (2.55). Control plots produced the lowest gross return, net return and BCR due to low yield. The overall economic performance of the aforesaid mungbean is sustainable and feasible considering applied STB nutrient management. The other best alternative nutrient managements were STB+CRI, IPNS, and IPNS+CRI. Nevertheless, STB+CRI nutrient management also gave higher net return compared to other nutrient managements like STB. Many scientists (Ali et al., 2009 a and b; Biswas et al., 2004, 2007, 2008; Zaman et al., $2007 \mathrm{a}$ and b) also conducted similar type of experiments with different cropping patterns without crop residue incorporation into the soil and found more or less similar results. However, STB and IPNS nutrient managements along with and without crop residue incorporation might be suitable for mungbean production as well as economic point of view.

Table 3. Economic performance of potato as influenced by different nutrient management (mean of 2006-07 and 2007-08)

\begin{tabular}{l|c|c|c|c}
\hline \multirow{1}{*}{$\begin{array}{c}\text { Nutrient } \\
\text { management }\end{array}$} & $\begin{array}{c}\text { Total cost } \\
\text { (Taka }\end{array}$ & $\begin{array}{c}\text { Gross return } \\
\text { (Taka }\end{array}$ & $\begin{array}{c}\text { Net return } \\
\text { (Taka) }\end{array}$ & BCR \\
\cline { 2 - 5 } & 1 & 2 & $3=(2-1)$ & $4=(2 / 1)$ \\
\hline HYG & 14788 & 37044 & 22256 & 2.51 \\
MYG & 13705 & 32232 & 18527 & 2.36 \\
IPNS & 15450 & 40844 & 25394 & 2.64 \\
STB & 13761 & 41224 & 27463 & 3.00 \\
FP & 8115 & 17117 & 9002 & 2.11 \\
CON & 7287 & 9123 & 1836 & 1.26 \\
HYG+CRI & 15355 & 37052 & 21696 & 2.41 \\
MYG+CRI & 14210 & 32363 & 18153 & 2.28 \\
IPNS+CRI & 16072 & 40981 & 24908 & 2.55 \\
STB+CRI & 14389 & 41859 & 27470 & 2.91 \\
FP+CRI & 8527 & 17387 & 8859 & 2.04 \\
CON+CRI & 7542 & 9880 & 2338 & 1.31 \\
\hline
\end{tabular}


Here, HYG=0-24-40-48-24-3-1.2, MYG=0-20-36-40-20-2-1, IPNS=5-9-37-3621-3-1.2, STB=0-20-36-40-22-2-1, FP=0-6-5-4-0-0-0, CON=0-0-0-0-0-0-0, CD (t ha-1), N, P, K, S, Zn, B $\left(\mathrm{kg} \mathrm{ha}^{-1}\right)$, respectively and CRI= Crop Residue Incorporation. $\mathrm{BCR}=$ Benefit-cost ratio $; \mathrm{MBCR}=$ Marginal benefit-cost ration

Input and output prices: Urea-6.50 (Tk. kg ${ }^{-1}$ ), TSP-19.00, MP-15.00, Gypsum4.60, Zincsulphate-65.00, Boric acid-100, Cowdung-0.32 and Crop reside- 0.25 (Tk. $\left.\mathrm{kg}^{-1}\right)$ (dry basis)

Mungbean seed -25 (Tk. $\left.\mathrm{kg}^{-1}\right)$ and Biomass-0.25 (Tk. $\left.\mathrm{kg}^{-1}\right)$ (dry basis)

\section{Conclusion}

Soil test based (0-20-36-40-22-2-1 CDNPKSZnB kg ha-1) and integrated plant nutrient system (5-9-37-36-21-3-1.2 CDNPKSZnB kg ha-1) along with or without crop residue incorporation could be suitable for getting higher seed yield with profitable cultivation of mungbean keeping sustainable good soil health.

\section{References}

Ahmed, Z.U., M.A.Q.A.I. Khan and A.K. Kaul.1978.Evaluation of local, exotic and mutant germplasm of mungbean for varietal characters and yield in Bangladesh. SABRAOJ. 10:48.

Akhteruzzaman, M., N.A. Mondal, K.U. Ahammad, J.A. Mahmud and M.A.H.S. Jahan. 2009. Integrated nutrient management for Wheat-Mungbean-T. Amanrice cropping pattern in high Ganges river floodplain soil. Eco-friendly Agril. J. 2(1): 322-326.

Ali, M.R., D.J. Costa, M.A. Sayed, M.A.H. Khan and J.A. Abedin.2009 (a).Development of fertilizer recommendation for the cropping pattern Potato-Boro-T.Aman in irrigated medium high land condition under AEZ-9. Bangladesh J. Agril. Res. 34(1):41-49.

Ali, M.R., D.J. Costa, M.A. Sayed, M.A. Rahman and M.H. Khan.2009 (b).Response of crops grown in Wheat-Jute-T.Amancropping pattern to added fertilizer nutrients in irrigated medium high land under AEZ 9. Bangladesh J. Agriculturist. 1(1):129-137.

BARC (Bangladesh Agricultural Research Council). 2005. Fertilizer Recommendation Guide-2005. Bangladesh Agril.Res. Council, New Airport Road, Farmgate, Dhaka.

Basak, N.C., M.A. Quayyum, S.M.Asaduzzaman, N. Sultana and M.A.H. Khan.2008.Integrated nutrient management in the Mustard-Boro rice-T.Aman rice cropping system. Bangladesh J. Agril. Res. 33(1): 135-143.

BBS (Bangladesh Bureau of Statistics). 2012. Statistical Year Book of Bangladesh. Bangladesh Bur. Stat., Plan. Div., Minis.Plan., Govt. People's Repub. Bangladesh. Dhaka, Bangladesh. Pp. 27-29.

Bhuiyan, M.A.H. 2004. Evaluation of introducing mungbean into cereal based cropping pattern for sustainable soil fertility and productivity. Ph D Thesis. Dept. of Soil Science, Bangladesh Agricultural University, Mymensingh. 
Biswas, J.C., M.R. Islam, S.R. Biswas and M.J. Islam.2004. Crop productivity at farmers field options for soil test based fertilizer use andcropping patterns. Bangladesh Agron. J. 10(1\&2): 31-41.

Biswas, J.C., M.R. Islam and M.J. Islam.2007. Crop Productivity as influenced by soil test based fertilizer management in six cropping patterns at farmers' field. SAARC J. of Agri. 5(1): 33-42.

Biswas, J.C., M. Maniruzzaman, M.A. Sattar and M.G. Neogi. 2008. Improvement of existing rice yield through recommended fertilizer and cultural management at farmers' fields. Bangladesh Rice J. 13(1): 9-14.

Chowdhury, J.A., M.A. Quayyum, J.Timsina, F. Haq and D.J. Connor. 2002. System productivity for Wheat-Mungbean/Maize-Rice sequences in northwest of Bangladesh. Bangladesh J. Agril. Res. 27(4): 619-627.

Kaul, A. 1982.Pulses in Bangladesh.Bnagladesh Agricultural Research Council. Farmgate, Dhaka, Pp. 27.

Khan, M.A.H., M.A. Quayyum, D.A. Choudhury, M.I. Nazrul and M.R. Ali. 2005. Integrated nutrient management for Potato-T. Aus-T.Aman rice cropping system. Bangladesh Agron. J. 11(1 \&2): 89-96.

Naser, H. M., N. C. Basak and M.F. Islam. 2001. Effect of rice straw and chemical fertilizers on the productivity and economics of Boro rice-Transplanted Aman rice system. Online J. Biol. Sci. 1 (9): 831-834.

Panaulah, G.M., M.A. Saleque, J. Timsina, M. Ishaque, A.B.M.B.U. Pathan, M.A. Quayyum, D.J. Connor, P.K. Saha, E. Humphreys and C.A. Meisner. 2006. Nutrient uptake and apparent balances for Rice-Wheat sequences. III. Potassium. Journal of Plant Nutrition 29: 173-187.

Quayyum, M.A., J. Timsina, F. Haq, G.S. Torofder and D.J. Connor. 2001. Effect of fertilizer and pre-monsoon crops on productivity of Rice (Oryzasativa)-Wheat (Triticumaestivum) cropping systems. Indian Journal of Agronomy 46 (4): 584-591.

Quayyum, M.A., J. Timsina, M.A.H.S. Jahan, R. Ara and D.J. Connor. 2002. Grain Yield and System Productivity for Rice-Wheat-Mungbean and Rice-Wheat-Maize Sequences in Northern Bangladesh. Thai J. Agric. Sci. 35(1): 51-62.

Rahman, M.A., M. Z. Abedin, M. N. Rahman and M. A. Siddiquee. 2002. Available potassium balance sheet for rainfed wheat based forage cropping system on the Old Brahmaputra Floodplain Soil. Bangladesh J. Sci. Ind. Res. 37(1-4):145:150.

Saha, P.K., M.A. Saleque, G.M. Panaullah and N.I. Bhuiyan. 2000. Fertilizer management for rice-based cropping system productivity. Bangladesh J. Agril. Res. 25(4): 565-573.

Saleque, M.A., J., Timsina, G.M. Panaulah, M. Ishaque, A.B.M.B.U. Pathan, M.A. Quayyum, D.J. Connor, P.K. Saha, E. Humphreys and C.A. Meisner. 2006. Nutrient uptake and apparent balances for Rice-Wheat sequences. II. Phosphorus. Journal of Plant Nutrition 28: 157-172.

Siag, P.K. and B.S. Yadav. 2003. Effect of levels and methods of sulphur application on growth and yield of mungbean. Indian Journal of Pulses Res. 16(2): 159-160. 
Singh, B. and R.G. Pareek. 2003. Effect of phosphorus and bio-fertilizers on growth and yield of mungbean. Indian Journal of Pulses Res. 16(1):31-33.

Singh, S.O., V.S. Kushwah and R.C. Sharma. 2003. Effect of fertilizers and residue incorporation on soil fertility in potato based cropping system. J. Indian Potato Assoc. 30(1-2): 103-104.

Timsina, J., U. Singh, M. Badaruddin, C.A. Meisner and M.R. Amin. 2001. Cultivar, nitrogen and water effects on productivity and nitrogen-use efficiency and balance for rice-wheat sequences of Bangladesh. Field Crop Research 72: 143-161.

Timsina, J., M.A. Quayyum, D.J. Connor, M. Saleque, F. Haq, G.M. Panaullah, M.A. H.S. Jahan and R.A. Begum.2006(a).Effect of fertilizer and mungbean residue management on total productivity, soil fertility and $\mathrm{N}$-use efficiency of intensified Rice-Wheat systems. International Journal of Agricultural Research 1(1): 41-52.

Timsina, J., G.M. Panaulah, M.A. Saleque, M. Ishaque, A.B.M.B.U Pathan, M.A. Quayyum, D.J. Connor, P.K. Saha, E. Humphreys and C.A. Meisner. 2006 (b).Nutrient uptake and apparent balances for Rice-Wheat sequences. I. Nitrogen. Journal of Plant Nutrition 29: 137-155.

Zaman, S.M., M.R. Amin, M.Y. Ali, M.A. Hossain and ShamimaAktar.2007 (a).Nutrient management in Boro-T.Aman cropping system under high Ganges river floodplain soil. Bangladesh J. Agron. and Environ. 3(2):55-63.

Zaman, S.M., M.R. Amin, Q. Naher, S. Aktar, M.K. Uddin and M.S. Rahman. 2007 (b). Evaluation of different nutrient management packages in Sesame-T. Aman cropping system under Ganges tidal floodplain. Intl. J. BioRes. 2(4):1-5. 